\title{
Post mortem identification of deoxyguanosine kinase $(D G U O K)$ gene mutations combined with impaired glucose homeostasis and iron overload features in four infants with severe progressive liver failure
}

\author{
Ewa Pronicka • Anna Wegglewska-Jurkiewicz • Joanna Taybert • Maciej Pronicki • \\ Tamara Szymańska-Dębińska • Agnieszka Karkucińska-Więckowska • \\ Joanna Jakóbkiewicz-Banecka • Paweł Kowalski • Dorota Piekutowska-Abramczuk • \\ Magdalena Pajdowska $\cdot$ Piotr Socha $\cdot$ Jolanta Sykut-Cegielska $\cdot$ Grzegorz Wegrzyn
}

Received: 15 June 2010 /Revised: 23 July 2010 / Accepted: 6 September 2010 /Published online: 16 November 2010

(C) The Author(s) 2010. This article is published with open access at Springerlink.com

\begin{abstract}
Deoxyguanosine kinase deficiency (dGK) is a frequent cause of the hepatocerebral form of mitochondrial depletion syndrome (MDS). A group of 28 infants with severe progressive liver failure of unknown cause was recruited for post mortem search for deoxyguanosine kinase $(D G U O K)$ gene mutations. Four affected patients (14\% of the studied group), two homozygotes, one compound heterozygote, and one heterozygote, with DGUOK mutation found on only one allele, were identified. Three known pathogenic mutations in the DGUOK gene were detected, c.3G $>$ A (p.Met1Ile), c.494A $>$ T (p.Glu165Val), and c.766_767insGATT (p.Phe256X), and one novel molecular variant of unknown pathogeneity, c.813_814insTTT (p. Asn271_Thr272insPhe). Profound mitochondrial DNA
\end{abstract}

Anna Weglewska-Jurkiewicz and Joanna Taybert contributed equally to this work.

E. Pronicka $(\bowtie) \cdot$ A. Węglewska-Jurkiewicz $\cdot$ J. Taybert •

J. Sykut-Cegielska

Department of Metabolic Diseases, Endocrinology and

Diabetology, Children's Memorial Health Institute (CMHI),

Aleja Dzieci Polskich 20,

04-730, Warsaw, Poland

e-mail: e.pronicka@czd.pl

A. Weglewska-Jurkiewicz·J. Jakóbkiewicz-Banecka •

G. Węgrzyn

Department of Molecular Biology, University of Gdańsk,

Gdańsk, Poland

\section{Pronicki · T. Szymańska-Dębińska •}

A. Karkucińska-Więckowska

Department of Pathology,

Children's Memorial Health Institute (CMHI),

Warsaw, Poland depletion was confirmed in available specimens of the liver $(4 \%, 15 \%$, and $10 \%$ of the normal value) and in the muscle $(4 \%, 23 \%, 45 \%$, and $6 \%$, respectively). The patients were born with low weights for gestational age and they presented adaptation trouble during the first days of life. Subsequently, liver failure developed, leading to death at the ages of 18, 6, 5.5, and 2.25 months, respectively. Mild neurological involvement was observed in all children (hypotonia, psychomotor retardation, and ptosis). Hypoglycemia (hypoketotic) and lactic acidosis were the constant laboratory findings. Elevated transferrin saturation, high ferritin, and alpha-fetoprotein levels resembled, in two cases, a neonatal hemochromatosis. Liver histopathology showed severe hepatic damage ranging from micronodular

P. Kowalski • D. Piekutowska-Abramczuk

Department of Medical Genetics,

Children's Memorial Health Institute (CMHI),

Warsaw, Poland

M. Pajdowska

Department of Biochemistry and Experimental Medicine,

Children's Memorial Health Institute (CMHI),

Warsaw, Poland

P. Socha

Department of Gastroenterology, Hepatology and Immunology,

Children's Memorial Health Institute (CMHI),

Warsaw, Poland 
formation and cirrhosis to the total loss of liver architecture with diffuse fibrosis and neocholangiolar proliferation. Pancreatic islet cell hyperplasia with numerous confluent giant islets was found in both autopsied infants. Analysis of the natural history of the disease in our patients and the literature data led us to the following observations: (i) islet cell hyperplasia (and hyperinsulinism) may contribute to MDSassociated hypoglycemia; (ii) iron overload may additionally damage mtDNA-depleted tissues; (iii) low birth weight, adaptation trouble, and abnormal amino acids in newborn screening are frequent in dGK-deficient neonates.

Keywords $D G U O K$ gene mutation - mtDNA depletion . Neonatal liver failure $\cdot$ Hypoglycemia $\cdot$ Iron overload Natural history of the disease

Hepatopathy is a prominent feature of mitochondrial depletion syndrome (MDS) caused by mutations in the nuclear genes encoding proteins responsible for mtDNA maintenance, replication, or nucleotide substrate delivery (POLG, DGUOK, and MPV17) (Dimmock et al. 2008). Since 1991, an increasing number of MDS has been reported among neonates, infants, and children who died due to progressive liver failure (Müller-Höcker et al. 2002; Rabinowitz et al. 2004). The disease is characterized by tissue-specific pathology, generally unusual for mitochondrial disorders.

Deoxyguanosine kinase deficiency (dGK) associated with mutations in the deoxyguanosine kinase (DGUOK) gene was uncovered as a genetic background of hepatic MDS phenotype by Mandel et al. in 2001 (Mandel et al. 2001). Since then, more than 50 patients from 35 affected families have been reported (Salviati et al. 2002; Mancuso et al. 2003; Filosto et al. 2004; Labarthe et al. 2005; Slama et al. 2005; Wang et al. 2005; Freisinger et al. 2006; Sarzi et al. 2007; Brahimi et al. 2009; Spinazzola et al. 2009). The $D G U O K$ gene mutations are considered to be the most common genetic background of hepatic MDS, being responsible for $14-20 \%$ of all mtDNA depletion cases (Salviati et al. 2002). Mitochondrial involvement in dGKdeficient patients is evidenced by lactic acidemia and impaired function of the respiratory chain (Mandel et al. 2001). Normal complex II activity (encoded by the nuclear genes) is a specific feature of MDS (Hargreaves et al. 2002).

Twenty-eight infants and children, who died due to progressive liver failure, were recruited for post mortem DGUOK gene mutations search. In all patients, a mitochondrial disease had been diagnosed before death. Two of them were included in the COX deficiency cohort described earlier (Böhm et al. 2006). The Bioethical Commission of the Children's Memorial Health Institute (CMHI) approved the study protocol.
Total DNA, extracted from skeletal muscle and liver samples, was used as a template to amplify seven coding exons of the $D G U O K$ gene. A set of primers corresponding to each exon and splicing regions of $D G U O K$ was used as described previously (Mandel et al. 2001).

The polymerase chain reaction (PCR) conditions were as follows: initial denaturation at $94^{\circ} \mathrm{C}$ for 2 min followed by 35 cycles at $94^{\circ} \mathrm{C}$ for $30 \mathrm{~s}, 62^{\circ} \mathrm{C}$ for $30 \mathrm{~s}, 72^{\circ} \mathrm{C}$ for $30 \mathrm{~s}$, and a final extension step at $72^{\circ} \mathrm{C}$ for $7 \mathrm{~min}$. Singlestranded DNA products were subjected to exonuclease I digestion and shrimp alkaline phosphatase hydrolysis (ExoSAP-IT), according to the manufacturer's protocol (USB Corp.), and subsequently sequenced. Sequencing reaction products were purified using DyeEx Kits prior to separation on an ABI 3730 Genetic Analyzer. The gathered data were analyzed using the Chromas Lite 2.01 software.

Sequence analysis revealed the presence of three known pathogenic mutations, c.3G $>$ A (p.Met1lle), c.494A $>\mathrm{G}$ (p.Glu165Val), and c.766_767insGATT (p.Phe256X), and one new molecular variant of unknown pathogeneity, c.813_814insTTT (p.Asn271_Thr272insPhe), in the DGUOK gene. There were two homozygotes, one compound heterozygote, and one affected patient with mutation found on only one chromosome.

The most frequent mutation identified in our study was the c. $3 \mathrm{G}>\mathrm{A}$ substitution in the $D G U O K$ exon 1 , potentially causing a severe impairment in the synthesis of the protein. It was found in two of our patients (in homozygous or heterozygous status, respectively) and it was reported previously only once, also in a patient of Polish origin (Freisinger et al. 2006).

The second mutation, revealed on only one allele in this study, was the frameshift 4-bp insertion in the DGUOK exon 6 (c.766_767insGATT). Since 2002, it has been reported in eight unrelated dGK-deficient patients from different regions of the world, especially from Arabian countries and Spain (Wang et al. 2005). The change is considered to be the most frequent and it was suggested to be either an ancient or a recurrent mutation (Salviati et al. 2002; Filosto et al. 2004; Labarthe et al. 2005).

The third known mutation located in exon 4 of the DGUOK gene (c.494A $>\mathrm{G})$ was found in our group in homozygous form in a child of seemingly unrelated parents. The change was reported in 2005 in one heterozygous French patient (Slama et al. 2005; Poulton et al. 2009).

The fourth change was not reported previously (c.813 814insTTT) and its pathogeneity requires further confirmation. Profound mitochondrial DNA depletion confirmed the diagnosis of MDS in this patient. The depletion was also found in all available tissue specimens, in the liver of the patients 1,2 , and $4(4 \%, 15 \%$, and $10 \%$ of the normal value, respectively), and in all of the patients' 
muscles $(4 \%, 23 \%, 45 \%$, and $6 \%$, respectively) (Weglewska et al. 2005; Węglewska-Jurkiewicz 2009).

The course of the disease in our four dGK-deficient patients resembled strikingly clinical features described in the literature (Mandel et al. 2001; Slama et al. 2005; Labarthe et al. 2005; Freisinger et al. 2006). Since remarkable difficulties in differential diagnosis were observed, an expended metabolic testing was required. A number of unusual or "strange" biochemical parameters (see Table 1) directed investigations to various different metabolic path- ways. More than ten genetic disorders (including tyrosinemia neonatal or type I, homocystnuria, 2- $\mathrm{CH}_{3}$-3-hydroxybutyric aciduria, galactosemia, hereditary fructose intolerance, cytrulinemia type II, biotinidase deficiency, Wilson disease, and lysosomal storage disorders) were suspected and subsequently excluded during the long-term hospitalizations in our referral metabolic center. The diagnosis of a mitochondrial disease was finally established in all four patients on the basis of the association of the lactic acidosis, neurological involvement (relatively mild), and cytochrome $\mathrm{C}$ oxidase

Table 1 Clinical characteristics and laboratory findings of the four patients with deoxyguanosine kinase $(D G U O K)$ gene mutations

\begin{tabular}{|c|c|c|c|c|}
\hline Patient & $\begin{array}{l}\text { Course of the disease; neurological } \\
\text { assessment }\end{array}$ & Specific biochemical abnormalities & DNA change & Protein change \\
\hline $\begin{array}{l}\text { Patient } 1 \\
\text { girl }\end{array}$ & $\begin{array}{l}\text { Two miscarriages. Low birth weight } \\
(2,570 \mathrm{~g}) ; 1 \mathrm{~d} \text { : hypoglycemia; } 2 \mathrm{~d} \text { : } \\
\text { hypotonia, vomiting, trembling; then: } \\
\text { hepatopathy, hypoglycemia; } 15 \mathrm{mo} \text { : } \\
\text { progression of hepatic dysfunction } \\
\text { to end-stage liver failure and death } \\
(18 \mathrm{mo}) \\
\text { Neurological status: nystagmus, } \\
\text { generalized hypotonia, psychomotor } \\
\text { retardation }\end{array}$ & $\begin{array}{l}\text { NBS: } \uparrow \text { methionine; } 6 \text { mo: GC-MS: } \uparrow \\
\text { 2- } \mathrm{CH}_{3}-3 \text {-OH-butyric acid, } \\
\text { 3-methylglutaconic acid; slightly } \uparrow \\
\text { lactic acid, p-OH phenylpyruvic acid } \\
\text { derivatives; CDT slightly } \uparrow(14.0 \% \text { ); } \uparrow \\
\text { CSF lactate; muscle biopsy: COX } \\
\text { deficiency } \\
\text { AFP } 9700,31000 \text {; Fe } 55 \text { TIBC } 322 \\
\text { (sat } 17 \% \text { ) }\end{array}$ & $\begin{array}{l}\text { c.766_767insGATT/ } \\
\text { c.? }\end{array}$ & $\begin{array}{l}\text { p.Phe256X/ } \\
\text { p.? }\end{array}$ \\
\hline \multirow[t]{2}{*}{$\begin{array}{l}\text { Patient } 2 \\
\text { girl }\end{array}$} & $\begin{array}{l}\text { Fetus hypotrophy ( } 29 \mathrm{Hbd}) \text {; caesarean } \\
\text { section due to fetus asphyxia (hbd } 35 \text {, } \\
1,859 \mathrm{~g}) ; 1 \mathrm{~d} \text { : hypotonia, weakness, } \\
\text { feeding difficulties, vomiting; } 4 \mathrm{~d} \text { : } \\
\text { hepatopathy, hypoglycemia ( } 26 \mathrm{mg} / \mathrm{dl} \text { ). } \\
\text { Since } 2.5 \text { mo: progression of liver } \\
\text { failure, ascites, severe coagulopathy, } \\
\text { cholestasis; died at the age of } 6.5 \text { mo }\end{array}$ & $\begin{array}{l}\text { NBS: } \uparrow \text { tyrosine; GC-MS: } \uparrow \text { lactic acid, } \\
\text { p-OH phenylpyruvic acid derivatives; } \uparrow \\
\text { galactose excretion in urine; } \uparrow \text { plasma } \\
\text { citrine; } \uparrow \text { plasma lactate }\end{array}$ & $\begin{array}{l}\text { c. } 3 \mathrm{G}>\mathrm{A} / \\
\text { c.813_814insTTT }\end{array}$ & p.Met1Ile/ \\
\hline & $\begin{array}{l}\text { Neurological status: hypotonia, } \\
\text { psychomotor retardation. }\end{array}$ & $\begin{array}{l}\text { AFP } 14500,18500,33500 ; \text { Fe } 25 \\
\quad \text { TIBC } 100 \text { (sat 25\%) }\end{array}$ & & $\begin{array}{l}\text { p.Asn271_ } \\
\text { Thr272insPhe }\end{array}$ \\
\hline \multirow[t]{2}{*}{$\begin{array}{l}\text { Patient } 3 \\
\text { girl }\end{array}$} & $\begin{array}{l}\text { Low birth weight }(2,640 \mathrm{~g}) ; 1 \mathrm{~d} \text { : severe } \\
\text { hypoglycemia, hypotonia, tachypnoea, } \\
\text { hypothermia, hepatomegaly, metabolic } \\
\text { acidosis, hypertransaminasemia; } 6 \text { mo: } \\
\text { progression of liver failure, coagulopathy, } \\
\text { ascites; death }\end{array}$ & $\begin{array}{l}\text { NBS: abnormal amino acids pattern. } \uparrow \\
\text { CK }(586-207 \mathrm{iU}) \text { at neonatal period: } \\
\text { GC-MS: } \uparrow \uparrow \text { lactic acid; p-OH } \\
\text { phenylpyruvic acid derivatives } \downarrow \text { serum } \\
\text { ceruloplasmin }(9 \mathrm{mg} / \mathrm{dl}) \text { and } \mathrm{Cu} \\
(36 \mathrm{mg} / \mathrm{dl}) \text {; normal urinary } \mathrm{Cu} \\
\text { excretion. Muscle biopsy: deficient } \\
\text { COX, low compl I }\end{array}$ & c. $3 \mathrm{G}>\mathrm{A} / \mathrm{c} .3 \mathrm{G}>\mathrm{A}$ & $\begin{array}{l}\text { p.Met1Ile/p. } \\
\text { Met1Ile }\end{array}$ \\
\hline & $\begin{array}{l}\text { Neurological status: hypotonia, } \\
\text { psychomotor retardation }\end{array}$ & $\begin{array}{l}\text { AFP } 9700,31000 \text {; ferritin } 287, \text { Fe } 138 \\
\text { TIBC } 184 \text { (sat } 75 \% \text { ) }\end{array}$ & & \\
\hline \multirow[t]{2}{*}{$\begin{array}{l}\text { Patient } 4 \\
\text { boy }\end{array}$} & $\begin{array}{l}\text { Low birth weight }(2,350 \mathrm{~g}) ; 1 \mathrm{~d} \text { : } \\
\text { generalized hypotonia, weakness, } \\
\text { hypoventilation, limbs edema, } \\
\text { hypoglycemia }(10 \mathrm{mg} / \mathrm{dl}) \text {. Then: } \\
\text { progressive liver dysfunction } \\
\text { (cholestasis, jaundice, coagulopathy, } \\
\text { ascites); } 10 \text { wks: death due to end- } \\
\text { stage liver failure }\end{array}$ & $\begin{array}{l}\text { Expended NBS ND; GC-MS: slightly } \uparrow \\
\text { lactic acid; p-OH phenylpyruvic acid } \\
\text { derivatives. Reducing substances in } \\
\text { urine - positive; } \uparrow \text { homocysteine; } \downarrow \\
\text { serum biotinidase activity; } \uparrow \text { plasma } \\
\text { and CSF lactate. Muscle biopsy: } \\
\text { deficient COX, low compl I }\end{array}$ & c. $494 \mathrm{~A}>\mathrm{T} / \mathrm{c} .494 \mathrm{~A}>\mathrm{T}$ & $\begin{array}{l}\text { p.Glu165Val/ } \\
\text { p.Glu165Val }\end{array}$ \\
\hline & $\begin{array}{l}\text { Neurological status: hypotonia, } \\
\text { psychomotor retardation }\end{array}$ & $\begin{array}{l}\text { AFP } 75000 \text {; ferritin } 1146 \text { Fe } 121 \text { TIBC } \\
139 \text { (sat } 87 \%)\end{array}$ & & \\
\hline
\end{tabular}

NBS, newborn screening; $\mathrm{CK}$, creatine kinase; $\mathrm{Cu}$, copper; $\mathrm{CDT}$, carbohydrate-deficient transferrin (test for congenital glycosylation disorder); GC-MS, gas chromatography-mass spectrometry method for assessment of the urinary profile of organic acids; COX, cytochrome C oxidase; compl, complex of the respiratory chain; AFP, alpha-fetoprotein (normal $<5 \mathrm{IU}$ ); Fe, iron (normal 37-145 $\mu \mathrm{g} / \mathrm{dl}$ ); TIBC, total iron binding capacity (normal 228-428 $\mu \mathrm{g} / \mathrm{dl}$ ); transferrin saturation normal value $<30 \%$; ferritin normal value 20-200 ng/dl; d, day(s); wks, weeks; mo, months; CSF, cerebrospinal fluid; ND, not determined 
deficiency (or combined oxidative phosphorylation [OXPHOS] defect) found in the muscle biopsy (not shown).

Liver histopathology showed, generally, two distinct patterns of damage. Patients 1 and 3 presented a similar model of parenchymal injury accompanied by bridging fibrosis leading to micronodular transformation and cirrhosis. This picture suggested at least some drive for hepatocytic regeneration. Patients 2 and 4 showed total loss of the liver architecture with diffuse fibrosis, neocholangiole proliferation, and no tendency for cirrhotic nodular transformation, as was shown earlier (Müller-Höcker et al. 2002; Mancuso et al. 2003; Rabinowitz et al. 2004; Labarthe et al. 2005). Focal remnants of the liver parenchyma were either necrotic or severely changed, suggesting early profound hepatocyte injury with subsequent domination of stromal and neocholangiolar reaction. Pancreatic islet cell hyperplasia with numerous confluent giant islets was found in both autopsied infants.

Generally, macro- and microscopic changes reported in the dGK deficiency (Filosto et al. 2004) were not found in the brain of our two autopsied patients. However, insufficient material from accurately identifiable sites to exclude the milder neuropathological features typical for mitochondrial depletion syndromes was available.

A retrospective analysis of the clinical course of the disease in our patients and the literature data led us to summarize some important common observations. Firstly, a relatively low birth weight $(<10$ th percentile), intrauterine growth retardation (IUGR), or prematurity was observed not only in our dGK-deficient patients but was also mentioned in 14 out of 19 values reported previously. The detection of mtDNA depletion in one affected fetus described additionally confirms a prenatal onset of the disease (Müller-Höcker et al. 2002).

Secondly, our observations suggest, for the first time, that an islet cell hyperplasia found at autopsy of two of our patients may contribute to hypoglycemia in dGK deficiency. Episodes of low glucose concentrations, lasting from the disease onset to the end-stage period, in all of our patients were observed. The hypoglycemia is regularly reported in the hepatic form of MDS, including dGK deficiency, but the impaired homeostasis background was not investigated. We clearly showed in our two patients that it depends on a relative hyperinsulinism (Fig. 1). The fasting test reveled the typical metabolic profile of low ketone and beta-hydroxybutyrate (BOB) production, relatively high insulin with lower free fatty acids (FFA) release, and increase of hyperglycemic hormones secretion (hGH, glucagon, cortisol) during hypoglycemia. Brisk response to intravenous glucagon injection (and the pancreatic autopsy findings mentioned above) seems to confirm the hypothesis.

The influence of hypoglycemia on the severity of liver dysfunction in the circumstances of mitochondrial energy

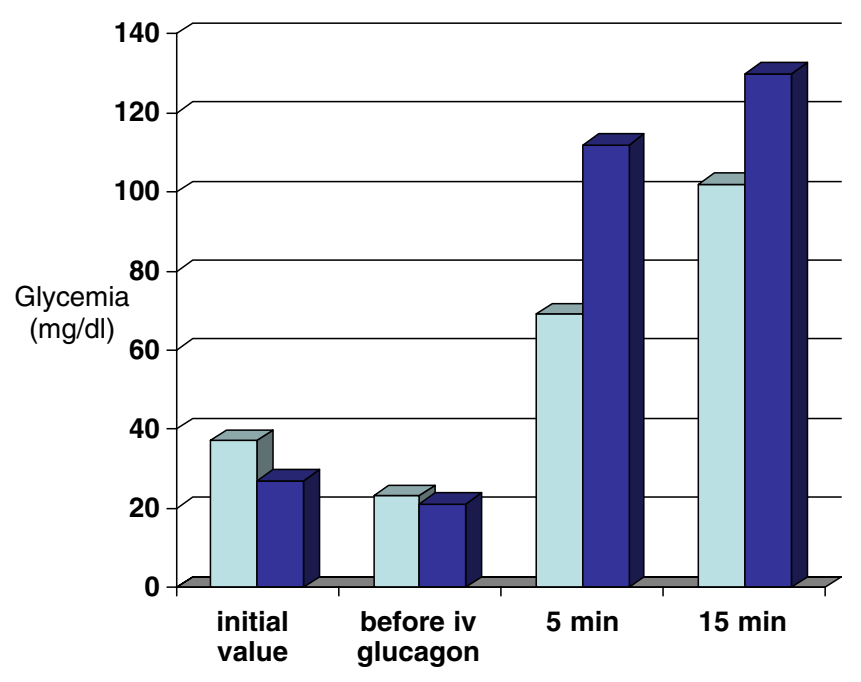

\begin{tabular}{|l|l|l|}
\hline $\begin{array}{l}\text { Biochemical parameters } \\
\text { before glucagon injection }\end{array}$ & $\begin{array}{l}\text { Patient 1 } \\
\text { blue }\end{array}$ & $\begin{array}{l}\text { Patient 2 } \\
\text { dark blue }\end{array}$ \\
\hline$\downarrow$ Glycemia mg/dl & 22.8 & 21.4 \\
$\downarrow$ Ketone bodies in urine $(+-+++)$ & 0 & 0 \\
$\downarrow$ BOB mmol/l & 0.21 & 0.15 \\
$\downarrow$ FFA mmol/l & 0.72 & 0.13 \\
N Cortisol ug/dl & 10.9 & 12.0 \\
$\uparrow$ Insulin mU/l & 4.3 & 5.7 \\
N C-peptide mU/l & 0.23 & 0.66 \\
$\uparrow$ hGH mlU/l & 31.6 & 34.3 \\
N ACTH pg/ml & 23 & 52 \\
$\uparrow$ Glucagon pg/ml & 186 & 560 \\
\hline
\end{tabular}

Fig. 1 Parameters of glucose homeostasis in two patients with deoxyguanosine kinase $(D G U O K)$ gene mutations during fasting hypoglycemia and after intravenous glucagon loading. $B O B$ serum beta-hydroxybutyrate (ketobutyrate) level; FFA serum free fatty acids level

shortage in MDS may be especially important. Recently, an improvement of the liver function on continuous intravenous glucose infusions and regular feeding was reported in the patients with MPV17 gene mutation (Parini et al. 2009). Our patients received systematically glucose infusions also, although the correlation between progression of the liver failure and the current glucose supply status was not possible to assess ex post.

Finally, some laboratory features of iron overload were revealed in our affected patients (Siafakas et al. 1997; Ponka 2002). Neonatal hemochromatosis was suspected initially in two of the patients and it was excluded by the pathological examination of the skin and the liver (not shown). However, significant abnormalities in the iron metabolism and transport were suggested by elevated transferrin saturation, relatively low total iron binding capacity (TIBC), and/or increased ferritin level (see Table 1). Theoretically, an excess of free iron ions may have deleterious toxic influence on the liver and subsequent organ damage (Visapää et al. 2002; Ramm and Ruddell 2005). An impaired function of the mitochondria 
associated with dGK deficiency may still aggravate the process. Decreased hepatic ATP content and reduced activity of the cytochrome $\mathrm{C}$ oxidase was observed in an experimental model of iron overload (Bacon et al. 1993). In one report describing a child with iron storage disease, a severe depletion of mtDNA (to $9 \%$ of the normal value) was mentioned ( $\mathrm{Vu}$ et al. 2001).

Interestingly, in our cohort, serum alpha-fetoprotein (AFP) elevation was constantly revealed (Table 1). On the dGK discovery, Mandel et al. rated serum AFP increase as being among the major biochemical findings (Mandel et al. 2001). Only a few other reports mentioned AFP levels (Rabinowitz et al. 2004), which ranged from $<2 \mathrm{ng} / \mathrm{ml}$ in an affected neonate to above $85,000 \mathrm{ng} / \mathrm{ml}$ or more in other reported cases. The high serum AFP associated with liver malignancy was described by Freisinger et al. in two dGK-deficient patients (Freisinger et al. 2006). Hepatic carcinoma (HCC) was not found in our patients by either liver ultrasound nor during autopsy. It cannot be excluded that the mechanism of the hyper-alpha-fetoproteinemia in dGK is connected with the liver regeneration process (like in tyrosinemia type I), and that, further, dGK-deficient patients will develop HCC if they survive for longer without transplantation (Scheers et al. 2005; Freisinger et al. 2006).

In our experience, an early appropriate identification of the mitochondrial pathology by the investigation of skeletal muscle biopsy (apparently not impaired) may prevent unnecessary escalation of the diagnostic procedures leading to misdiagnoses and inadequate treatment.

A better understanding of the primary or secondary factors influencing liver damage in MDS (including hypoglycemia and iron overload) may contribute to the improvement of the short- and long-term prognosis in children with the hepatic form of this mitochondrial disorder.

Acknowledgments The authors thank Prof. Takeyori Saheki from Tokushima, Japan, for the molecular exclusion of cytrulinemia type II in patient 1, and Prof. Ron Wanders from Amsterdam, The Netherlands, for the enzymatic exclusion of 2-methyl-3-hydroxybutyric aciduria in patient 2.

The study was supported by grant no. PB 0890/P05/2005/29 and the Polish Mitochondrial Network.

Open Access This article is distributed under the terms of the Creative Commons Attribution Noncommercial License which permits any noncommercial use, distribution, and reproduction in any medium, provided the original author(s) and source are credited.

\section{References}

Bacon BR, O’Neill R, Britton RS (1993) Hepatic mitochondrial energy production in rats with chronic iron overload. Gastroenterology 105 (4):1134-1140

Böhm M, Pronicka E, Karczmarewicz E, Pronicki M, PiekutowskaAbramczuk D, Sykut-Cegielska J, Mierzewska H, Hansikova H,
Vesela K, Tesarova M, Houstkova H, Houstek J, Zeman J (2006) Retrospective, multicentric study of 180 children with cytochrome C oxidase deficiency. Pediatr Res 59:21-26

Brahimi N, Jambou M, Sarzi E, Serre V, Boddaert N, Romano S, de Lonlay P, Slama A, Munnich A, Rötig A, Bonnefont JP, Lebre AS (2009) The first founder DGUOK mutation associated with hepatocerebral mitochondrial DNA depletion syndrome. Mol Genet Metab 97:221-226

Dimmock DP, Dunn JK, Feigenbaum A, Rupar A, Horváth R, Freisinger P, Mousson de Camaret B, Wong L-J, Scaglia F (2008) Abnormal neurological features predict poor survival and should preclude liver transplantation in patients with deoxyguanosine kinase deficiency. Liver Transpl 14:1480 1485

Filosto M, Mancuso M, Tomelleri G, Rizzuto N, Dalla Bernardina B, DiMauro S, Simonati A (2004) Hepato-cerebral syndrome: genetic and pathological studies in an infant with a dGK mutation. Acta Neuropathol (Berl) 108:168-171

Freisinger P, Fütterer N, Lankes E, Gempel K, Berger TM, Spalinger J, Hoerbe A, Schwantes C, Lindner M, Santer R, Burdelski M, Schaefer H, Setzer B, Walker UA, Horváth R (2006) Hepatocerebral mitochondrial DNA depletion syndrome caused by deoxyguanosine kinase $(D G U O K)$ mutations. Arch Neurol 63:1129-1134

Hargreaves P, Rahman S, Guthrie P, Taanman JW, Leonard JV, Land JM, Heales SJ (2002) Diagnostic value of succinate ubiquinone reductase activity in the identification of patients with mitochondrial DNA depletion. J Inherit Metab Dis 25:716

Labarthe F, Dobbelaere D, Devisme L, De Muret A, Jardel C, Taanman J-W, Gottrand F, Lombès A (2005) Clinical, biochemical and morphological features of hepatocerebral syndrome with mitochondrial DNA depletion due to deoxyguanosine kinase deficiency. J Hepatol 43:333-341

Mancuso M, Filosto M, Tsujino S, Lamperti C, Shanske S, Coquet M, Desnuelle C, DiMauro S (2003) Muscle glycogenosis and mitochondrial hepatopathy in an infant with mutations in both the myophosphorylase and deoxyguanosine kinase genes. Arch Neurol 60:1445-1447

Mandel H, Szargel R, Labay V, Elpeleg O, Saada A, Shalata A, Anbinder Y, Berkowitz D, Hartman C, Barak M, Eriksson S, Cohen N (2001) The deoxyguanosine kinase gene is mutated in individuals with depleted hepatocerebral mitochondrial DNA. Nat Genet 29:337-341

Müller-Höcker J, Muntau A, Schäfer S, Jaksch M, Staudt F, Pongratz D, Taanman J-W (2002) Depletion of mitochondrial DNA in the liver of an infant with neonatal giant cell hepatitis. Hum Pathol 33:247-253

Parini R, Furlan F, Notarangelo L, Spinazzola A, Uziel G, Strisciuglio P, Concolino D, Corbetta C, Nebbia G, Menni F, Rossi G, Maggioni M, Zeviani M (2009) Glucose metabolism and dietbased prevention of liver dysfunction in MPV17 mutant patients. J Neurol 50:215-221

Ponka P (2002) Rare causes of hereditary iron overload. Semin Hematol 39:249-262

Poulton J, Hirano M, Spinazzola A, Arenas Hernandez M, Jardel C, Lombès A, Czermin B, Horváth R, Taanman JW, Rötig A, Zeviani M, Fratter C (2009) Collated mutations in mitochondrial DNA (mtDNA) depletion syndrome (excluding the mitochondrial gamma polymerase, POLG1). Biochim Biophys Acta 1792:1109-1112

Rabinowitz SS, Gelfond D, Chen C-K, Gloster ES, Whitington PF, Sacconi S, Salviati L, DiMauro S (2004) Hepatocerebral mitochondrial DNA depletion syndrome: clinical and morphologic features of a nuclear gene mutation. J Pediatr Gastroenterol Nutr 38:216-220 
Ramm GA, Ruddell RG (2005) Hepatotoxicity of iron overload: mechanisms of iron-induced hepatic fibrogenesis. Semin Liver Dis 25:433-449

Salviati L, Sacconi S, Mancuso M, Otaegui D, Camaño P, Marina A, Rabinowitz S, Shiffman R, Thompson K, Wilson CM, Feigenbaum A, Naini AB, Hirano M, Bonilla E, DiMauro S, Vu TH (2002) Mitochondrial DNA depletion and dGK gene mutations. Ann Neurol 52:311-317

Sarzi E, Bourdon A, Chrétien D, Zarhrate M, Corcos J, Slama A, Cormier-Daire V, de Lonlay P, Munnich A, Rötig A (2007) Mitochondrial DNA depletion is a prevalent cause of multiple respiratory chain deficiency in childhood. J Pediatr 105:531-534

Scheers I, Bachy V, Stephenne X, Sokal EM (2005) Risk of hepatocellular carcinoma in liver mitochondrial respiratory chain disorders. J Pediatr 146:414-417

Siafakas CG, Jonas MM, Perez-Atayde AR (1997) Abnormal bile acid metabolism and neonatal hemochromatosis: a subset with poor prognosis. J Pediatr Gastroenterol Nutr 25:321-326

Slama A, Giurgea I, Debrey D, Bridoux D, de Lonlay P, Levy P, Chrétien D, Brivet M, Legrand A, Rustin P, Munnich A, Rötig A (2005) Deoxyguanosine kinase mutations and combined deficiencies of the mitochondrial respiratory chain in patients with hepatic involvement. Mol Genet Metab 86:462-465
Spinazzola A, Invernizzi F, Carrara F, Lamantea E, Donati A, Dirocco M, Giordano I, Meznaric-Petrusa M, Baruffini E, Ferrero I, Zeviani M (2009) Clinical and molecular features of mitochondrial DNA depletion syndromes. J Inherit Metab Dis $32: 143-158$

Visapää I, Fellman V, Vesa J, Dasvarma A, Hutton JL, Kumar V, Payne GS, Makarow M, Van Coster R, Taylor RW, Turnbull DM, Suomalainen A, Peltonen L (2002) GRACILE syndrome, a lethal metabolic disorder with iron overload, is caused by a point mutation in BCS1L. Am J Hum Genet 71:863-876

Vu TH, Tanji K, Holve SA, Bonilla E, Sokol RJ, Snyder RD, Fiore S, Deutsch GH, DiMauro S, De Vivo D (2001) Navajo neurohepatopathy: a mitochondrial DNA depletion syndrome? Hepatology 34:116-120

Wang L, Limongelli A, Vila MR, Carrara F, Zeviani M, Eriksson S (2005) Molecular insight into mitochondrial DNA depletion syndrome in two patients with novel mutations in the deoxyguanosine kinase and thymidine kinase 2 genes. Mol Genet Metab 84:75-82

Węglewska-Jurkiewicz A (2009) PhD thesis, Gdańsk, Poland

Węglewska A, Jakóbkiewicz-Banecka J, Węgrzyn G (2005) A modified procedure for quantitative analysis of mtDNA, detecting mtDNA depletion. J Appl Genet 46:423-428 